\title{
Conversion of the $\omega$ subunit of Escherichia coli RNA polymerase into a transcriptional activator or an activation target
}

\author{
Simon L. Dove and Ann Hochschild ${ }^{1}$ \\ Department of Microbiology and M olecular Genetics, Harvard M edical School, Boston, Massachusetts 02115 USA
}

\begin{abstract}
Evidence obtained in both eukaryotes and prokaryotes indicates that arbitrary contacts betwen DNA-bound proteins and components of the transcriptional machinery can activate transcription. Here we demonstrate that the Escherichia coli $\omega$ protein, which copurifies with RNA polymerase, can function as a transcriptional activator when linked covalently to a DNA-binding protein. We show further that $\omega$ can function as an activation target when this covalent linkage is replaced by a pair of interacting polypeptides fused to the DNA-binding protein and to $\omega$, respectively. Our findings imply that the $\omega$ protein is associated with RNA polymerase holoenzyme in vivo, and provide support for the hypothesis that contact between a DNA-bound protein and any component of $E$. coli RNA polymerase can activate transcription.
\end{abstract}

[Key Words: $\omega$ subunit; E. coli; RNA polymerase; transcriptional activator]

Received December 3, 1997; revised version accepted January 15, 1998.

Recent findings in both eukaryotes and prokaryotes indicate that arbitrary protein-protein contacts can trigger gene activation provided one of the protein partners is tethered to the DNA and the other is a component (or is tethered to a component) of RNA polymerase (RNAP) (Barberis et al. 1995; Chatterjee and Struhl 1995; Klages and Strubin 1995; Xiao et al. 1995; Apone et al. 1996; Farrell et al. 1996; Dove et al. 1997; Gaudreau et al. 1997; Gonzalez-Couto et al. 1997; Lee and Struhl 1997; for review, see Ptashne and Gann 1997). Experiments in yeast have shown further that direct fusion of a DNA-binding domain to a component of the RN AP II holoenzyme can activate transcription from a promoter bearing a recognition site for the DN A-binding domain (Barberis et al. 1995; Farrell et al. 1996; Gaudreau et al. 1997; for review, see Ptashne and Gann 1997), but analogous experiments have not been performed previously in bacteria.

RNAP in Escherichia coli consists of an enzymatic core composed of subunits $\alpha, \beta$, and $\beta^{\prime}$ in the stoichiometry $\alpha_{2} \beta \beta^{\prime}$, and one of several alternative $\sigma$ factors that confer on the enzyme the ability to recognize specific promoters (Burgess 1976; Hellman and Chamberlin 1988). An additional protein, omega $(\omega)$, has been called a subunit of RN AP on the basis of its copurification with RNAP core and holoenzyme in near stoichiometric amounts (Burgess 1969). The function of $\omega$ is unknown and, unlike the other subunits, $\omega$ is not required for tran-

${ }^{1}$ Corresponding author.

E-MAIL ahochsch@warren.med.harvard.edu; FAX (617) 738-7664. scription either in vitro (Heil and Zillig 1970) or in vivo (Gentry and Burgess 1989; Gentry et al. 1991). Cells deleted for the gene encoding $\omega$ (rpoZ) have no discernible mutant phenotypes (Gentry and Burgess 1989; Gentry et al. 1991).

M any natural activators in bacteria bind the DNA near the promoters they regulate and interact directly with one or more subunits of RN AP (Busby and Ebright 1994). The best known target of these interactions is the $\alpha$ subunit of RN AP (Ishihama 1992; Russo and Silhavy 1992; Ebright and Busby 1995; Niu et al. 1996). Some activators, however, interact with the $\sigma$ subunit (Hochschild 1994; Kuldell and Hochschild 1994; Li et al. 1994; Artsimovitch et al. 1996; Gerber and Hinton 1996), and evidence suggests that the $\beta$ subunit may also serve as an activation target in at least one case (Lee and Hoover 1995). Finally the $\beta^{\prime}$ subunit has been identified as the target of action of an activator that functions without binding to the DNA (Miller et al. 1997). In contrast, the $\omega$ subunit has not been implicated in activation to date.

In a previous study we fused a heterologous protein domain to the $\alpha$ subunit of E. coli RNAP and demonstrated that interaction between a DNA-bound protein and the heterologous protein domain tethered to $\alpha$ activated transcription from a test promoter (Dove et al. 1997). The magnitude of the activation correlated with the strength of the protein-protein interaction, the interaction presumably functioning to stabilize the binding of RNAP to the promoter. These findings suggest that contact between a DN A-bound protein and any sub- 
unit of RN AP could, in principle, activate transcription.

Here we show that coval ent linkage of a DNA-binding protein to the $\omega$ subunit can activate transcription from a test promoter bearing a recognition site for the DNAbinding domain, and further that this covalent linkage can be replaced by a protein-protein bridge. These results support the hypothesis that any subunit of RN AP can serve as an activation target, and provide evidence that the $\omega$ protein is associated with RN AP holoenzyme in vivo and that it is accessible at the surface of the enzyme complex.

\section{Results}

The $\omega$ subunit can activate transcription from a test promoter when fused to a DNA-binding protein

To determine whether the $\omega$ subunit of RNAP can mediate transcriptional activation when tethered to the DNA upstream of a promoter, we fused the $\omega$ protein to the repressor $(\mathrm{cl})$ protein of bacteriophage $\lambda$ (see Fig. 1B). The $\lambda \mathrm{cl}$ protein is a two-domain protein that binds DN A as a dimer; the amino-terminal domain (NTD) is the DN A-binding domain, whereas the carboxy-terminal domain (CTD) mediates dimer formation (and higher order oligomerization) (Sauer et al. 1990).

We fused the entire $\omega$ protein (residues 1-90) to the carboxyl terminus of the $\lambda \mathrm{cl}$ protein through a small alanine linker (see Materials and Methods). We placed the gene encoding this fusion protein downstream of an in-

A

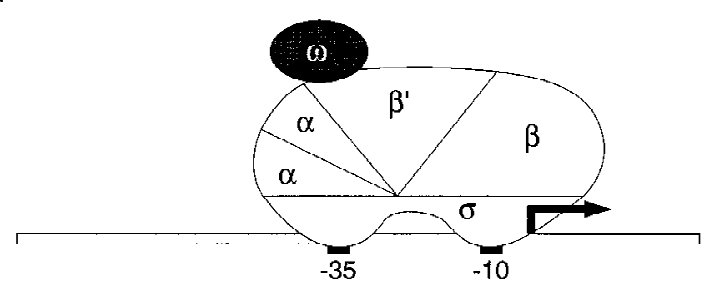

B

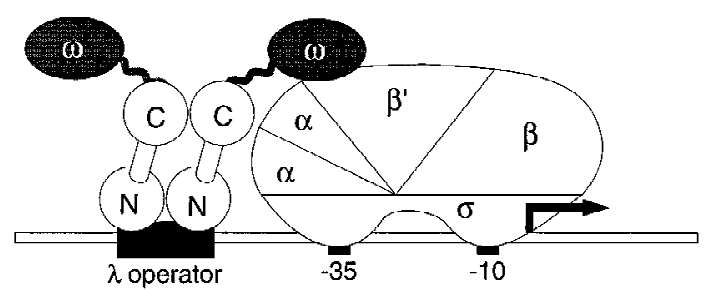

Figure 1. (A) Basal transcription by E. coli RN A polymerase. A promoter comprised of a -10 and a -35 element is depicted bound by RN AP with subunit composition $\alpha_{2} \beta \beta^{\prime} \sigma \omega$. The $\omega$ subunit (shaded) is depicted as interacting with the $\beta^{\prime}$ subunit as a monomer (see Gentry and Burgess 1993). (B) Fusion of the $\omega$ subunit of RNAP to the carboxy terminus of $\lambda \mathrm{Cl}$ permits interaction of a modified polymerase with a $\lambda$ operator. The artificial promoter derivative plac $\mathrm{O}_{\mathrm{R}} 2-62$ is shown; it bears the $\lambda$ operator $\mathrm{O}_{\mathrm{R}} 2$ centered 62 bp upstream of the transcriptional start site of the lac promoter. ducible promoter on a plasmid vector, thus generating plasmid $\mathrm{pBRCl}-\omega$. We introduced $\mathrm{pBRcl}-\omega$ into strain $\mathrm{KS} 1 \Delta \mathrm{Z}$, which harbors on its chromosome a lac promoter derivative (termed placO $_{\mathrm{R}} 2-62$ ) bearing a single $\lambda$ operator centered 62 bp upstream of the transcription start point. $\mathrm{N}$ ote that $\lambda \mathrm{cl}$, which activates transcription from the $\lambda P_{R M}$ promoter when bound at a site centered at position -42 , cannot activate transcription from placO $_{R}$ 2-62 (Dove et al. 1997) because the $\lambda$ operator is positioned too far from the promoter. In addition, $\mathrm{KS} 1 \Delta \mathrm{Z}$ bears a deletion of the chromosomal locus encoding the $\omega$ subunit. Unlike $\lambda \mathrm{Cl}$, the $\lambda \mathrm{Cl}-\omega$ fusion protein stimulated transcription $\sim 70$-fold, as measured by $\beta$-gal actosidase assay (Fig. 2A). Primer extensi on analysis confirmed that the fusion protein stimulated the production of correctly initiated transcripts (Fig. 2B). A similar experiment performed with strain $\mathrm{KS} 1$ reveal ed that the $\lambda \mathrm{Cl}-\omega$ fusion protein was unable to stimulate transcription from placO $\mathrm{R}_{\mathrm{R}} 2-62$ in the presence of endogenous $\omega$ protein encoded by the chromosomal rpoZ gene (Fig. 2A).

Transcriptional activation by the $\lambda \mathrm{Cl}-\omega$ fusion protein is dependent on its ability to bind DNA

To demonstrate that the stimulation of transcription from placO ${ }_{\mathrm{R}}^{2-62}$ in $\mathrm{KS} 1 \Delta \mathrm{Z}$ by $\lambda \mathrm{Cl}-\omega$ depends on the ability of the fusion protein to bind to the $\lambda$ operator of placO $\mathrm{R}_{\mathrm{R}} 2-62$, we introduced a single amino acid substitution (S45A) into the $\lambda \mathrm{Cl}$ moiety of the fusion protein that results in a severe reduction in operator binding (Hochschild and Ptashne 1986). This mutant version of the $\lambda \mathrm{cl}-\omega$ fusion protein failed to stimulate transcription from placO $_{\mathrm{R}}$ 2-62 (Fig. 2A).

We confirmed that the $\lambda \mathrm{cl}(\mathrm{S} 45 \mathrm{~A})-\omega$ fusion protein is specifically defective for operator binding by measuring its binding to a consensus $\lambda$ operator using an in vivo repression assay (data not shown). Western blot analysis confirmed that the $\lambda \mathrm{Cl}-\omega$ and the $\lambda \mathrm{cl}$ (S45A)- $\omega$ fusion proteins were present in the cell in comparable amounts (data not shown).

Interaction between a DNA-bound domain of Gal4 and a domain of Gal $11^{\mathrm{P}}$ fused to either the $\alpha$ or $\omega$ subunit of RNAP results in transcriptional activation from a test promoter

We then replaced the coval ent interaction between the $\lambda \mathrm{cl}$ protein and the $\omega$ subunit of RNAP with a proteinprotein contact. For this purpose we took advantage of a pair of protein domains originally shown to interact in yeast cells. Transcriptional activation in yeast can be triggered by an apparently fortuitous interaction between the dimerization region of the yeast transcriptional activator Gal4 and a mutant form of the Gall1 protein (Himmelfarb et al. 1990; Barberis et al. 1995), which despite its name, is a component of the RN AP II holoenzyme and is required for full transcription of many genes (Kim et al. 1994; Barberis et al. 1995; Hengartner et al . 1995). Ordi narily, in yeast, the dimerization 
A

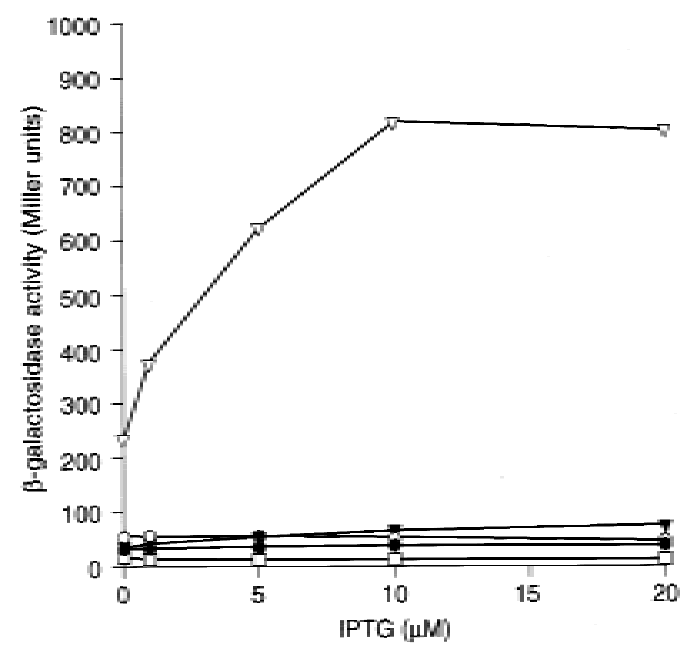

B

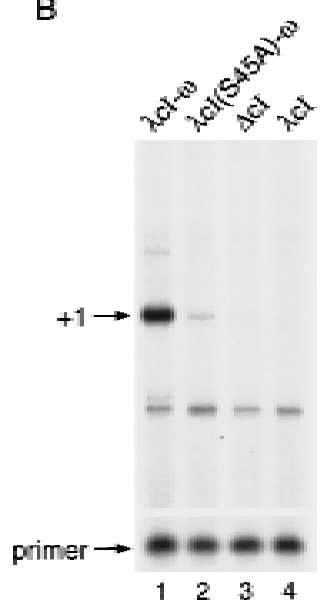

Figure 2. Transcriptional activation by $\lambda \mathrm{Cl}-\omega$ fusion protein. (A) Effect of $\lambda \mathrm{Cl}-\omega$ on transcription in vivo from plac $\mathrm{O}_{\mathrm{R}} 2-62$. $\mathrm{KS} 1 \Delta Z$ cells harboring plasmids encoding either $\lambda \mathrm{cl}-\omega(\nabla), \lambda \mathrm{cl}(\mathrm{S} 45 \mathrm{~A})-\omega(\boldsymbol{\nabla}), \lambda \mathrm{cl}(\square)$ or no $\lambda \mathrm{cl}(\Delta \mathrm{Cl})(\bigcirc)$, and KSl cells (containing wild-type $\omega)(\bullet)$ harboring a plasmid encoding $\lambda \mathrm{Cl}-\omega$, were grown in the presence of the indicated concentrations of IPTG and assayed for $\beta$-galactosidase activity. (B) Primer extension analysis of transcripts produced from placO $_{\mathrm{R}} 2-62$ in the presence of $\lambda \mathrm{Cl}-\omega$. Total RNA was isolated from $\mathrm{KS} 1 \Delta \mathrm{Z}$ cells grown in the presence of $20 \mu \mathrm{M}$ IPTG and harboring plasmids encoding the indicated proteins. Primer extension analysis was done by using a primer complementary to the lac $Z$ transcript produced by the placO $_{\mathrm{R}}$ 2-62 promoter. Primer extension products produced by correctly initiated plac $O_{R} 2-62$ transcripts are indicated by +1 and excess unincorporated primer is shown.

region of Gal4 does not mediate transcriptional activation when connected to its own or another DNA-binding domain. However, in the presence of a Gall1 mutant (called Gal $11^{\mathrm{P}}$ for potentiator) bearing a single amino acid substitution at position 342, the Gal 4 dimerization regi on functions as a powerful activating region; this activation results from a specific interaction between the Gal 4 di merization regi on and the portion of $\mathrm{Gal} 11^{\mathrm{P}}$ bearing the amino acid substitution (Barberis et al. 1995; Farrell et al. 1996).

To establish that this protein-protein interaction can al so trigger gene activation in $\mathrm{E}$. coli, we first tested the abilities of the rel evant portions of $\mathrm{Gal} 11^{\mathrm{P}}$ and Gal 4 (Farrell et al. 1996) to mediate transcriptional activation when fused to the $\alpha$ subunit of RNAP and to the $\lambda \mathrm{cl}$ protein, respectively. To do this, we proceeded as we had done previously (Dove et al. 1997), taking advantage of the domain structure of $\alpha$, which initiates the assembly of RN AP by forming a dimer. The $\alpha$-NTD is responsible for the assembly reaction (Hayward et al. 1991; Igarashi et al. 1991), and the $\alpha$-CTD, which is connected to the $\alpha$-NTD by a flexible linker region (Blatter et al. 1994; Jeon et al. 1997), can bind DN A (Ross et al. 1993; Blatter et al. 1994) and is the natural target for many transcriptional activators (Ishihama 1992; Ebright and Busby 1995). We reasoned that if we replaced the $\alpha-C T D$ with an appropriate domain of $\mathrm{Gal} 11^{\mathrm{P}}$, the resulting $\alpha-\mathrm{Gal} 11^{\mathrm{P}}$ chimera would display a target that could be contacted by an appropriately positioned $\lambda \mathrm{Cl}-\mathrm{Gal} 4$ dimer (Fig. 3). Therefore, we created two chimeric genes, one encoding the $\alpha$-NTD and linker connected to residues 263-352 of Gal $11^{\mathrm{P}}$, and the other encoding full-length $\lambda \mathrm{cl}$ (residues 1-236) connected to the dimerization region of Gal4 (residues 58-97) (see Materials and Methods). We then tested the ability of the $\lambda \mathrm{cl}-\mathrm{Gal} 4$ fusion protein to activate transcription from placO $_{\mathrm{R}} 2-62$ in cells containing the $\alpha-$ Gal $11^{\mathrm{P}}$ fusion protein (as well as wild type $\alpha$ encoded by the chromosomal rpoA gene). Figure 4A shows that the $\lambda \mathrm{Cl}-\mathrm{Gal} 4$ fusion protein activated transcription $\sim 45$-fold in KSI cells containing the $\alpha-$ Gal $11^{\mathrm{P}}$ fusion protein but not in control cells containing an otherwise identical fusion protein bearing the wild type form of Gal11. Primer extension analysis confirmed that the fusion protein stimulated the production of correctly ini-

A

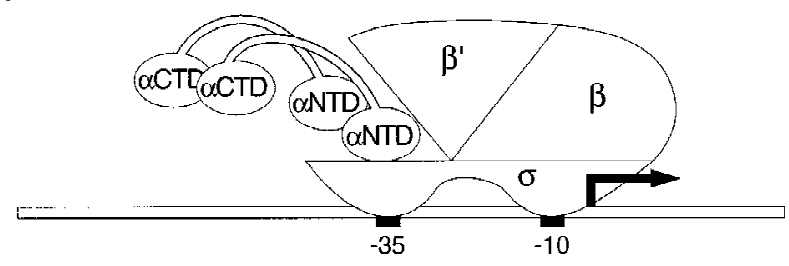

B

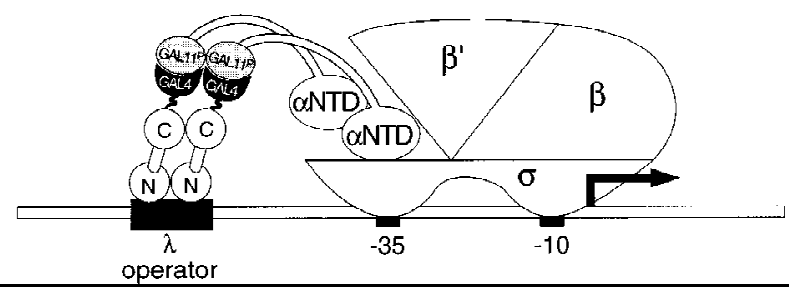

Figure 3. (A) Basal transcription by E. coli RNA polymerase drawn to illustrate the structure of the $\alpha$ subunit. A promoter comprised of $a-10$ and $a-35$ el ement is depicted together with the subunit composition of RN AP holoenzyme. The $\alpha$ subunits of RN AP consist of two independently folded domains; an NTD and a CTD connected by a flexible linker. (B) Replacement of RNAP $\alpha$-CTD by Gal $11^{P}$ (residues 263-352) permits interaction with the $\mathrm{Gal} 4$ dimerization domain of a $\lambda \mathrm{Cl}-\mathrm{Gal} 4$ fusion protein. The diagram depicts the test promoter placO $_{R} 2-62$, which bears the $\lambda$ operator $\mathrm{O}_{\mathrm{R}} 2$ centered 62 bps upstream of the transcriptional start site of the lac promoter. 
tiated transcripts (Fig. 4B). We also found that a different $\lambda \mathrm{Cl}-\mathrm{Gal} 4$ fusion protein comprising only the NTD and linker regi on of $\lambda \mathrm{Cl}$ (residues 1-132) fused to Gal4(58-97) activated transcription in $\mathrm{KS} 1$ cells harboring the $\alpha-$ Gal $11^{\mathrm{P}}$ fusion protein by a factor of approximately eight (data not shown)

A

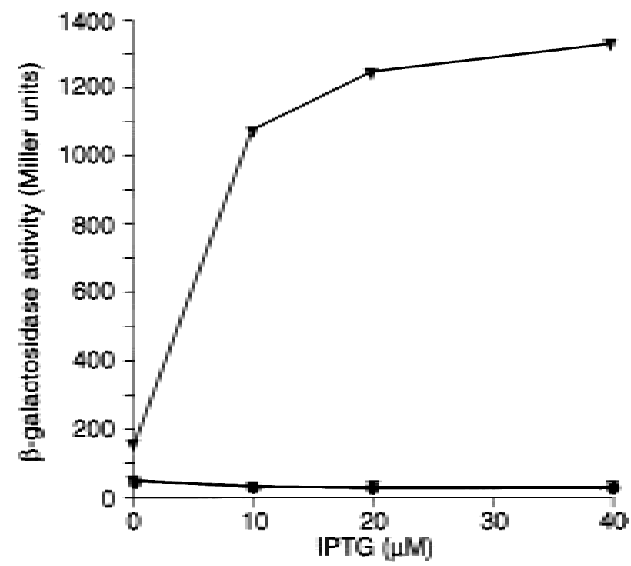

B

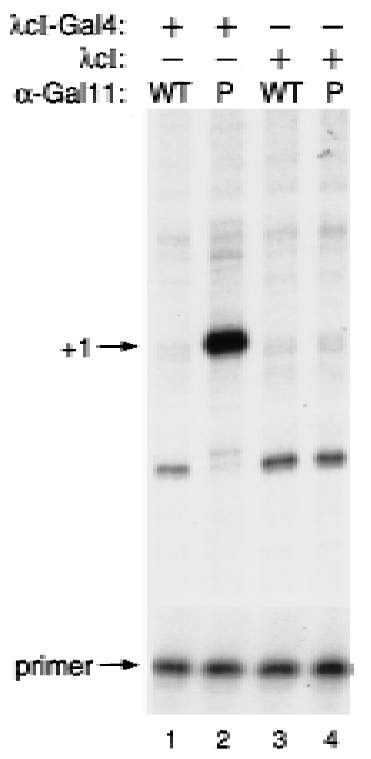

Figure 4. Transcriptional activation by $\lambda \mathrm{cl}-\mathrm{Gal} 4$ fusion protein in presence of $\alpha-G$ al $11^{P}$ fusion protein. (A) Effect of $\lambda \mathrm{Cl}-$ Gal 4 on transcription in vivo from plac $O_{R} 2-62$ in the presence of $\alpha-G a l 11^{P}$ fusion protein. $\mathrm{KS} 1 \Delta Z$ cells harboring plasmids expressing the indicated proteins were grown in the presence of different concentrations of IPT G and assayed for $\beta$-gal actosi dase activity. ( $\boldsymbol{\nabla}) \lambda \mathrm{Cl}-\mathrm{Gal} 4+\alpha-\mathrm{Gal} 11^{\mathrm{P}} ;(\nabla) \lambda \mathrm{Cl}-\mathrm{Gal} 4+\alpha-\mathrm{Gal} 11^{\mathrm{WT}}$; (O) $\lambda \mathrm{Cl}+\alpha-\mathrm{Gal} 11^{\mathrm{P} ;}(\mathrm{O}) \lambda \mathrm{Cl}+\alpha-\mathrm{Gal} 11^{\mathrm{WT}}$. (B) Primer extension analysis of transcripts produced from plac $\mathrm{O}_{\mathrm{R}} 2-62$ in the presence of $\lambda \mathrm{cl}-\mathrm{Gal} 4$ and $\alpha-\mathrm{Gal} 11^{\mathrm{P}}$. Total RNA was isolated from $\mathrm{KS} 1 \Delta \mathrm{Z}$ cells grown in the presence of $20 \mu \mathrm{M}$ IPT G and harboring plasmids encoding the indicated proteins. Primer extension analysis was done by using a primer complementary to the lac $Z$ transcript produced by the plac $\mathrm{O}_{\mathrm{R}} 2-62$ promoter. Primer extension products produced by correctly initiated plac $\mathrm{O}_{\mathrm{R}} 2-62$ transcripts are indicated by +1 and excess unincorporated primer is shown.
We reasoned that if we fused the appropriate domain of Gal $11^{\mathrm{P}}$ to the $\omega$ subunit of RNAP the resulting $\omega-\mathrm{Gal} 11^{\mathrm{P}}$ chimera would, li ke the $\alpha-\mathrm{Gal} 11^{\mathrm{P}}$ chimera, display a target that could be contacted by an appropriately positioned $\lambda \mathrm{Cl}-\mathrm{Gal} 4$ dimer (Fig. 5A). Therefore, we constructed a chimeric gene encoding the $\omega$ subunit connected to residues 263-352 of Gal $11^{\mathrm{P}}$ (see M aterials and $\mathrm{M}$ ethods). Figure 5B shows that the $\lambda \mathrm{Cl}-\mathrm{Gal} 4$ fusion protein (comprising residues 1-236 of $\lambda \mathrm{cl}$ fused to residues 58-97 of Gal4) activated transcription $~ 20$-fold in $\mathrm{KS} 1 \Delta \mathrm{Z}$ cells containing the $\omega-\mathrm{Gal} 11^{\mathrm{P}}$ fusion protein, but not in control cells containing the $\omega-\mathrm{Gal} 11^{\mathrm{WT}}$ fusion protein. Primer extension anal ysis confirmed that the fusion protein stimulated the production of correctly initiated transcripts (Fig. 5C). In contrast to the $\lambda \mathrm{Cl}-\omega$ fusion protein, the $\lambda \mathrm{Cl}-\mathrm{G}$ al 4 fusion protein activated transcription in $\mathrm{KS} 1$ cells containing both wild-type $\omega$ and the $\omega$ Gal $11^{P}$ chimera (data not shown), indicating that in this case endogenous $\omega$ does not compete effectively with the $\omega-\mathrm{Gal} 11^{\mathrm{P}}$ chimera for binding to RN AP (see Discussion).

\section{Discussion}

Transcriptional activation in E. coli by tethering a subunit of RNAP to DNA

We have demonstrated that coval ent linkage of a DN Abinding protein $(\lambda \mathrm{Cl})$ to a component of RNAP $(\omega)$ results in transcriptional activation from a promoter bearing a recognition site for the DN A-binding protein (a $\lambda$ operator). This form of activation resembles the natural activation that occurs when the RNAP $\alpha$ subunit interacts with a DNA sequence element termed the UP element that is found upstream of the -35 hexamer of rRN A promoters (as well as some other promoters) (Ross et al. 1993; Gaal et al. 1996). As mentioned above, the $\alpha$ subunit has two domains, and its CTD is a sequence-specific DNA-binding domain (Blatter et al. 1994; Gaal et al. 1996). The interaction of the $\alpha$-CTD with naturally occurring UP elements has been reported to increase transcription by as much as 30-fold, and this increase reflects an increase in the initial binding of RNAP to the promoter and possibly a subsequent step in the initiation process (Ross et al. 1993; Rao et al. 1994).

Experiments performed in eukaryotic cells have also shown that transcription can be activated by the direct fusion of DNA-binding domains to various components of the transcriptional machinery. For example, fusion of the $\mathrm{E}$. coli LexA repressor, a sequence-specific DNAbinding protein, to the wild-type $\mathrm{Gal} 11$ protein creates a powerful transcriptional activator in yeast that works on promoters bearing LexA-binding sites, and this activation depends on the portion of Gall1 that mediates its association with the RN AP II hol oenzyme (Himmelfarb et al. 1990; Barberis et al. 1995; see also Farrell et al. 1996; Gaudreau et al . 1997). Similarly, direct or indirect fusion of a DNA-binding domain to the yeast TATAbinding protein (TBP) creates a transcriptional activator that works on promoters bearing a recognition site for the DNA-binding domain upstream of the TATA ele- 
A
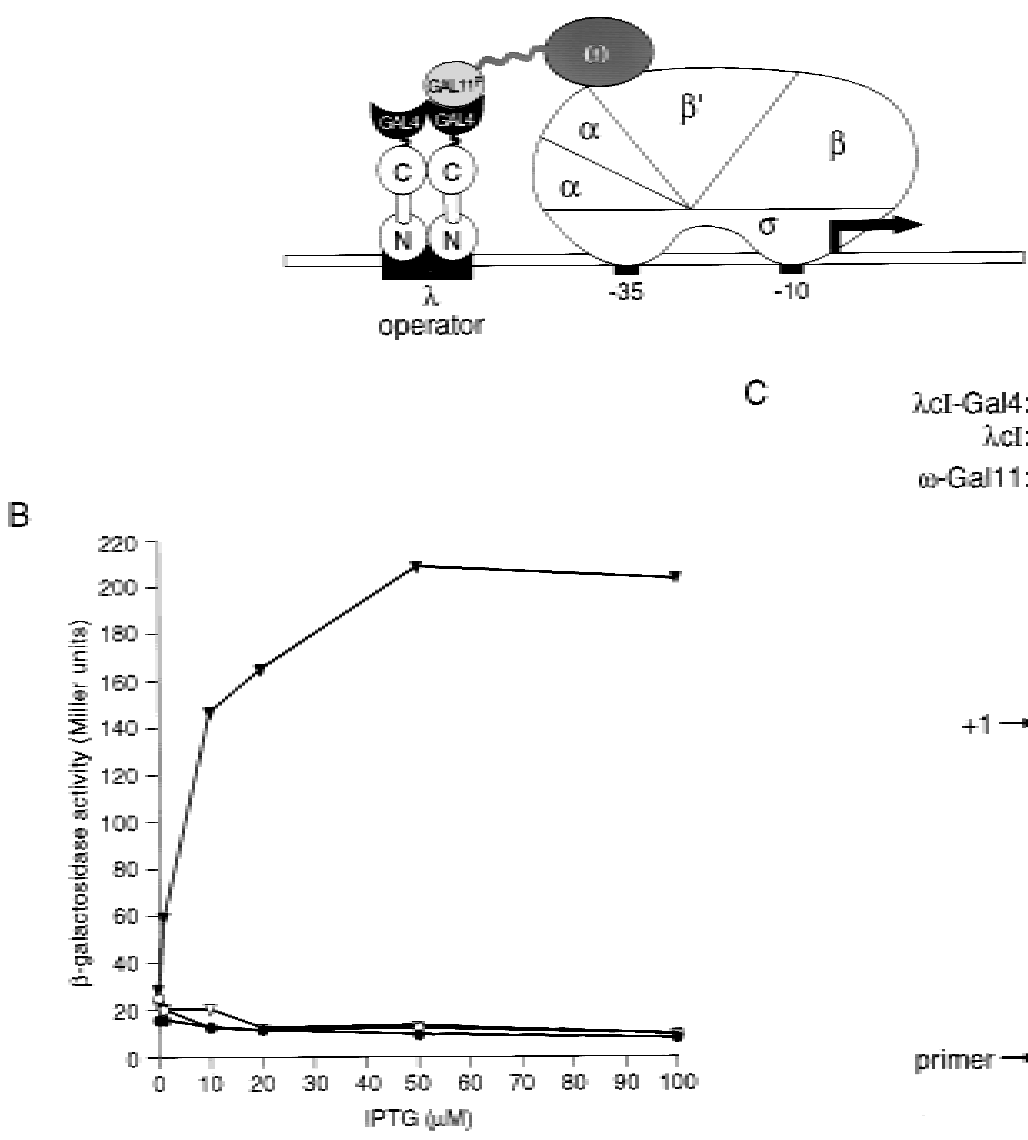

c

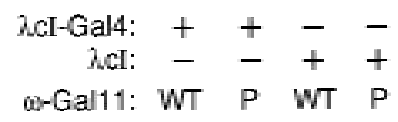

Figure 5. Transcriptional activation by $\lambda \mathrm{Cl}-\mathrm{Gal} 4$ fusion protein in presence of $\omega-\mathrm{Gal} 11^{\mathrm{P}}$ fusion protein. (A) Fusion of $\mathrm{Gal} 11^{\mathrm{P}}$ (resi dues 263-352) to the $\omega$ subunit of RN A polymerase permits interaction with the Gal 4 dimerization domain of a $\lambda \mathrm{cl}-\mathrm{Gal} 4$ fusion protein. The diagram depicts the test promoter plac $\mathrm{O}_{R} 2-62$, which bears the $\lambda$ operator $\mathrm{O}_{R} 2$ centered 62 bp upstream of the transcriptional start site of the lac promoter. (B) Effect of $\lambda \mathrm{cl}-\mathrm{Gal} 4$ on transcription in vivo from plac $\mathrm{O}_{\mathrm{R}} 2-62$ in the presence of $\omega$-Gal $11^{\mathrm{P}}$ fusion protein. $\mathrm{KS} 1 \Delta \mathrm{Z}$ cells harboring plasmids expressing the indicated proteins were grown in the presence of different concentrations of IPTG and assayed for $\beta$-gal actosi dase activity. $(\boldsymbol{\nabla}) \lambda \mathrm{Cl}-\mathrm{Gal} 4+\omega-\mathrm{Gal} 11^{\mathrm{P}} ;(\nabla) \lambda \mathrm{Cl}-\mathrm{Gal} 4+\omega-\mathrm{Gal} 11^{\mathrm{WT}} ;(\bullet) \lambda \mathrm{Cl}+\omega-\mathrm{Gal} 11^{\mathrm{P}} ;(O) \lambda \mathrm{Cl}+\omega-\mathrm{Gal} 11^{\mathrm{WT}}$. (C) Primer extension analysis of transcripts produced from plac $\mathrm{O}_{R} 2-62$ in the presence of $\lambda \mathrm{cl}-\mathrm{G}$ al 4 and $\omega-\mathrm{Gal} 11^{\mathrm{P}}$. Total RN A was isolated from KS1 $\Delta Z$ cells grown in the presence of $50 \mu \mathrm{M}$ IPTG and harboring plasmids encoding the indicated proteins. Primer extension analysis was done by using a primer complementary to the lac $Z$ transcript produced by the plac $\mathrm{O}_{\mathrm{R}} 2-62$ promoter. Primer extension products produced by correctly initiated plac $\mathrm{O}_{\mathrm{R}} 2-62$ transcripts are indicated by +1 and excess unincorporated primer is shown.

ment, and this activation depends on the ability of TBP to interact with the TATA element (Chatterjee and Struhl 1995; Klages and Strubin 1995; Xiao et al. 1995). Thus, recruitment of the polymerase II holoenzyme and TBP to promoters in yeast cells, as well as RN AP holoenzyme to bacterial promoters can bea rate-limitingstep in transcription initiation in vivo.

Transcriptional activation by arbitrary protein-protein interactions

In a previous study we showed that contact between a DNA-bound protein and a heterologous protein domain fused to the $\alpha$-NTD can activate transcription in E. coli (Dove et al. 1997). We have now general ized this finding by showing that an interacting pair of protein fragments that triggers gene activation in yeast also triggers gene activation in $\mathrm{E}$. coli when one of the pair is fused to a DN A-binding protein and the other is fused either to the $\alpha-N T D$ or to the $\omega$ protein. Specifically, we fused the dimerization domain of $\mathrm{Gal} 4$ to the $\lambda \mathrm{cl}$ protein and the relevant fragment of the $\mathrm{Gal} 11^{\mathrm{P}}$ protein either to the $\alpha-N T D$ or to $\omega$ and demonstrated that the $\lambda \mathrm{cl}-\mathrm{Gal} 4 \mathrm{fu}-$ sion protein stimulated transcription from an appropriately designed test promoter in cells containing either the $\alpha-\mathrm{Gal} 11^{\mathrm{P}}$ or the $\omega-\mathrm{Gal} 11^{\mathrm{P}}$ fusion protein. These findings provide support for the hypothesis that contact between a DNA-bound protein and any component of RNAP can activate transcription in E. coli (Fig. 6). In particular, they indicate that the $\alpha$ subunit is not unique in its ability to mediate the effects of artificial activators.

We note that the $\lambda \mathrm{Cl}-\mathrm{Gal} 4$ fusion protein stimulated 


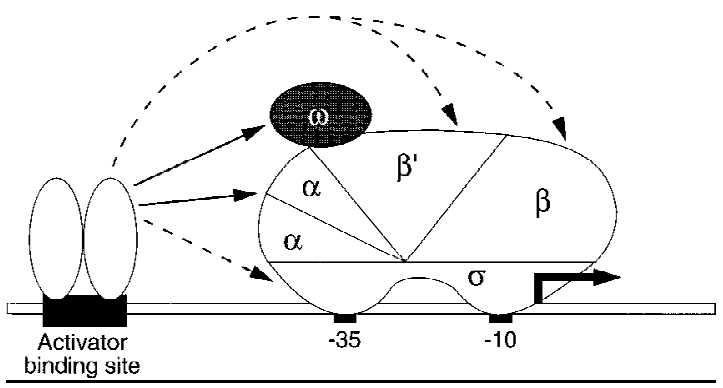

Figure 6. Any subunit of RNAP can serve as an activation target. An activator bound upstream of a promoter is depicted, and the possible interactions with any of the subunits of RNAP are illustrated with arrows. The interactions mediated by the artificial activators described herein are indicated by solid arrows; additional interactions are indicated by broken arrows. The $\alpha$ and $\sigma$ subunits are known targets of natural DNA-bound activators (for review, see Busby and Ebright 1994), the $\beta$ subunit is suggested as a target for at least one DNA-bound activator (Lee and Hoover 1995), and the $\beta^{\prime}$ subunit is the target of an activator that works without binding DNA (Miller et al. 1997).

transcription more strongly with the $\alpha-G$ al $11^{P}$ than with the $\omega$-Gal $11^{P}$ fusion protein (45- vs. 20-fold). We do not know the reason for this difference, but we speculate that it may reflect a difference in the number of $\mathrm{Gal} 11^{\mathrm{P}}$ moieties displayed by the RNAP holoenzyme in the two cases. Whereas the $\omega$ subunit is presumed to associate with RN AP as a monomer, the $\alpha$ subunit assembles as a dimer. Therefore, at least a fraction of the polymerase molecules assembled in the presence of chromosomally encoded wild-type $\alpha$ and an excess of the $\alpha-G a l 11^{P}$ fusion protein should display two $\mathrm{Gal} 11^{\mathrm{P}}$ moieties, each of which might be able to interact with a Gal 4 moiety displayed on the DNA-bound $\lambda \mathrm{cl}$ dimer. It is also possible that the observed difference in activities (45-fold for the $\alpha-G a l 11^{P}$ fusion protein and 20 -fold for the $\omega-G a l 11^{P}$ fusion protein) reflects a difference in the fraction of RNAP molecules in the cell that contain the fusion protein. Further experiments will be required to test these possibilities.

The $\omega$ protein is a subunit of RNA polymerase in vivo

Our demonstration that the $\omega-\mathrm{Gal} 11^{\mathrm{P}}$ fusion protein can function as an activation target provides strong evidence that the $\omega$ protein is associated with RNAP in growing cells. This demonstration taken together with the finding that the $\lambda \mathrm{Cl}-\omega$ fusion protein is a powerful activator of transcription indicates, moreover, that $\omega$ is accessible at the surface of RN AP. Therefore, our results raise the possibility that $\omega$ might serve as a target for natural DN A-bound activators, as well.

In our experiments with the $\lambda \mathrm{Cl}-\omega$ fusion protein (in which the amino terminus of $\omega$ is fused to the carboxyl terminus of $\lambda \mathrm{cl}$ ), we observed transcriptional activation only in a strain deleted for the chromosomal rpoZ gene (encoding $\omega$ ). This suggests first that the $\lambda \mathrm{Cl}-\omega$ fusion protein associates with the same surface of RNAP as native $\omega$ protein, and second, that the native $\omega$ protein associates preferentially. In contrast, the $\omega-\mathrm{Gal} 11^{\mathrm{P}}$ fusion protein (in which the amino terminus of $\omega$ is free) mediated transcriptional activation by the $\lambda \mathrm{cl}-\mathrm{Gal} 4 \mathrm{fu}-$ sion protein in both the absence and presence of chromosomally encoded $\omega$ protein. This suggests that this fusion protein competes effectively with native $\omega$ protein for association with RNAP. We suggest a possible explanation: The amino-terminal portion of the $\omega$ protein mediates its association with RN AP with the consequence that fusion of another protein at the amino terminus weakens the association.

In vitro cross-linking experiments have suggested that $\omega$ binds to the $\beta^{\prime}$ subunit of RN AP (Gentry and Burgess 1993). The biological activity of our $\lambda \mathrm{Cl}-\omega$ fusion protein should permit genetic identification of not only the residues on $\omega$ that mediate its association with RNAP, but the interacting residues on $\beta^{\prime}$ (or any other subunit of RN AP) as well.

Practical implications for prokaryotic two-hybrid and one-hybrid systems

Our previous demonstration that contact between a DN A-bound protein and a protein domain fused to the $\alpha$ subunit of RNAP can activate transcription suggested the possibility of establishing a transcription-based twohybrid assay for detecting protein-protein interactions in E. coli (Dove et al. 1997). Here we have demonstrated the feasi bility of this approach by showing that two polypeptides known to interact in yeast and in vitro (Farrell et al. 1996) can activate transcription in E. coli when one of the pair is fused to a subunit of RN AP (either $\alpha$ or $\omega$ ) and the other is fused to a DNA-binding protein $(\lambda \mathrm{Cl})$.

Previous studies have demonstrated that heterol ogous protein domains that mediate dimer formation can functionally substitute for the $\lambda \mathrm{Cl}-\mathrm{CTD}$ when fused to the $\lambda \mathrm{Cl}-\mathrm{NTD}$, resulting in biologically active fusion proteins that bind efficiently to $\lambda$ operators (for review, see $\mathrm{Hu}$ 1995). In designing the $\lambda \mathrm{Cl}-\mathrm{Gal} 4$ fusion protein, we sought to compare the effects of fusing the Gal 4 moiety to the end of the $\lambda \mathrm{cl}$ linker (at residue 132) and to the end of full-length $\lambda \mathrm{cl}$ (at residue 236). Although both of the resulting fusion proteins bound to $\lambda$ operators and stimulated transcription in the presence of the $\alpha-G a l 11^{P}$ fusion protein (Fig. 4; data not shown), the full-length $\lambda \mathrm{Cl}-$ Gal4 fusion protein was more active, presumably because the $\lambda \mathrm{cl}-\mathrm{CTD}$ mediates more efficient dimerization than the Gal4 moiety. The finding that a heterologous protein domain can be fused to the carboxyl terminus of $\lambda \mathrm{cl}$ without interfering with $\lambda \mathrm{cl}$-CTD-mediated dimerization implies that heterol ogous protein domains can be tethered to the DNA through the $\lambda \mathrm{cl}$ protein regardless of whether or not they have the potential to dimerize.

The utility of this strategy was confirmed by our construction of a biologically active $\lambda \mathrm{Cl}-\omega$ fusion protein. In turn, the ability of this fusion protein to activate transcription from a promoter bearing a $\lambda$ operator demonstrates the feasibility of establishing a so-called "one- 
hybrid" assay in E. coli to detect specific protein-DNA interactions (Li and Herskowitz 1993; Wang and Reed 1993; Inouye et al. 1994).

\section{Mechanistic implications}

Together our findings with both the $\alpha$ and the $\omega$ fusion proteins suggest that depending on the nature of the promoter, contact between a DNA-bound protein and any accessible surface of RNAP can activate transcription, presumably by stabilizing the binding of RNAP to the promoter. We suspect, however, that this form of activation would not work at all promoters. In particular, if the activity of a given promoter is not limited by its ability to stably bind RNAP in vivo (for example, see Morett and Buck 1989; Hidalgo and Demple 1997; for reviews, see also Kustu et al. 1991; Summers 1992; Gralla 1996; Ptashne and Gann 1997), then we hypothesize that the artificial activators we have designed would be ineffective. In this regard, it might be possible to use the $\lambda \mathrm{Cl}-\omega$ fusion protein as a tool for classifying promoters in vivo.

\section{Materials and methods}

Media, growth conditions, and genetic techniques

Bacteria were cultured routinely in L broth or on L-agar plates (Miller 1972). Where needed, antibiotics were used at the following concentrations: carbenicillin $(50 \mu \mathrm{g} / \mathrm{ml})$, chloramphenicol $(25 \mu \mathrm{g} / \mathrm{ml})$, kanamycin $(50 \mu \mathrm{g} / \mathrm{ml})$, and tetracycline $(20 \mu \mathrm{g} /$ $\mathrm{ml}$ ). Transductions were performed using general ized transducing phage Plvir as described previously (Sternberg and Maurer 1991).

\section{Bacterial strains}

E. coli strain XL1-blue (Stratagene) was used routinely as a cloning vehicle for plasmid constructions. The E. coli strain KSI has been described previously (Dove et al. 1997) and harbors the artificial promoter derivative placO $_{\mathrm{R}} 2-62$ consisting of the $\lambda$ operator $\mathrm{O}_{\mathrm{R}} 2$ centered 62 bp upstream of the transcriptional start site of the lac promoter. This promoter and thelinked lacZ gene are present on a $\lambda \mathrm{imm} 21$ prophage. The $\mathrm{E}$. coli strain $\mathrm{KS} 1 \Delta Z$ was created by P1-mediated transduction of the $\Delta$ spoS3::cat mutation (an $\omega$ null al lele) from CF2790 (Xiao et al. 1991 ) into recipient strain KS1.

\section{DNA manipulation and oligonucleotides}

Standard molecular biology techniques (Sambrook et al. 1989) were used for cloning, DN A purification, and analysis. The PCR was performed using Expand (Boehringer $M$ annheim) and restriction enzymes were obtained from $\mathrm{New}$ England Biolabs. DNA was sequenced by the dideoxy method using Sequenase (U.S. Biochemical).

Oligonucleotides used to make the different plasmids were purchased from Operon Technologies, Inc., and were as follows: OL.2 (5'-CAGTGATTCTGCATTCTGGCTTGAG-3'); OL.3 (5'-GCGGATCCTAGGTCAAAATAATCCTGTTAA-3'); OL.6 (5'-CAGACGTTTGGCGAATCAAGGCTAGAAAGACTGG3'); OL.7 (5'-TAGCCTTGATTCGCCAAACGTCTCTTCAGG$\left.3^{\prime}\right) ;$ OL.13 (5'-CTGCTGTTGAGGCTCTGGTTTCTCTTCTTTCAC-3'); OL.15 (5'-GAGAAACCAGAGCCTCAACAGCAG-
CAAATGCAACC-3'); OL.18 (5'-AGCGGATCCTCACAAAGCTTGGATTTTTCTCAGG-3'); OL.R1 (5'-GTGCCGGTTCTACCC-3'); OL.32 (5'-TAGGATCCGGCGCGCCTAAGATCTTGCGGCCGCGCCAAACGT CTCTTCAGGC CACTG-3'); OL.39 (5'-ATATGCGGCCGCACGCGTAACTGTTCAGGACG-3'); OL.40 (5'-ATATGTCGACTTAACGACGACCTTCAGCAAT-3'); OL.41 (5'-AAAGTTCCATATGGCACGCGTAACTGTTCAGG-3'); OL.42 (5'-TATATGCGGCCGCACGACGACCTTCAGCAATAGCG-3'); OL.43 (5'-ATATGCGGCCGCACCTCAACAGCAGCAAATGCAACC-3'); OL.44 (5'-ATATGTCGACTCACAAAGCTTGGATTTTTCTCAGG-3'); OL.54 (5'-ATATATCATATGAGCACAAAAAAGAAACC-3'); OL.55 (5'-TTCTCTGGCGATTGAAGGGC-3').

\section{Plasmids}

Plasmids used in this study are listed in Table 1 . All inserts in plasmids that were generated by the PCR were subsequently sequenced to confirm that no errors had been introduced as a result of the PCR process.

Plasmid pLX20 is a derivative of pBR322 (Bolivar et al. 1977), confers $A p^{R}$, and bears the $\mathrm{Cl}$ gene under the control of the lacUV5 promoter ( $F$. Whipple, unpubl.).

Plasmid $\mathrm{pBRCl}-\omega$ is a derivative of $\mathrm{pLX} 20$, confers $A p^{R}$, and encodes residues 1-236 of $\lambda \mathrm{cl}$ fused to two Ala residues, which in turn are fused to residues 1-90 of the $\omega$ subunit of E. coli RNAP. The expression of the $\lambda \mathrm{Cl}-\omega$ fusion protein is under the control of the lacUV 5 promoter. The primary sequence of the $\lambda \mathrm{Cl}-\omega$ fusion protein junction from $\lambda \mathrm{cl}$ residue 235 inclusive is PheGIyAlaAlaAlaArg, where the underlined residues are the first and second, respectively, in the primary sequence of $\omega$. $N$ ote that the initiating $M$ et of $\omega$ was not included in the fusion protein, as it is not present in the mature protein (Gentry and Burgess 1986), and therefore, the Ala residue that follows the initiating $M$ et is classified here as residue one. $\mathrm{pBRcl}-\omega$ was constructed by replacing the HindIII-Sall fragment from pLX20 with two fragments of DNA. One fragment (comprising a segment of the $\mathrm{Cl}$ gene) was a HindllI-N otl-digested PCR product that was made using primers OL.2 and OL.32 with pAC $\lambda \mathrm{Cl}$ as template. This fragment contains a Notl site at the $3^{\prime}$ end of $\mathrm{Cl}$. The second fragment (comprising the $\omega$ gene) was a N otl-Salldigested PCR product that was made using primers OL.39 and OL.40 with $\mathrm{pE} \Delta \mathrm{C}-1$ as template.

Plasmid pBRcl(S45A)- $\omega$ is identical to pBRcl- $\omega$ except that the $\lambda \mathrm{Cl}$ moiety of the fusion protein harbors the S45A mutation. pBRcl(S45A)- $\omega$ was constructed by replacing the $\mathrm{Ndel}-\mathrm{N}$ sil fragment from $\mathrm{pBRCl}-\omega$ with an $\mathrm{N}$ del-N sil-digested PCR product that was made using primers OL.54 and OL.55 with pLCF3 as template. $\mathrm{pBR} \Delta \mathrm{cl}$ is the same as pLR1 $\Delta \mathrm{cl}$ (Whipple et al. 1994).

Plasmid pACLGF2 is a derivative of $\mathrm{pAC} \lambda \mathrm{cl}$, confers $\mathrm{Cml} \mathrm{l}^{\mathrm{R}}$, and encodes residues 1-236 of $\lambda \mathrm{cl}$ fused to residues 58-97 of Gal 4 under the control of the lacU V 5 promoter. pACLGF2 was made by replacing the HindlII-BstYI fragment from pAC $\lambda \mathrm{Cl}$ with a HindIII-BamHI digested PCR product made using primers OL.2 and OL.3. The PCR product comprised a fragment of the 3' end of the cl gene fused directly to the coding sequence of Gal 4 (residues 58-97), and two PCR products (made using primers OL. 2 and OL.7 with $\mathrm{PAC} \lambda \mathrm{Cl}$ as template and primers OL.6 and OL. 3 with pN S113 as template, respectively) served as template for its generation.

Plasmid pACTCLGF2 is a derivative of PACLGF2 that confers $T c^{R}$ and like pACLGF2 encodes residues 1-236 of $\lambda \mathrm{cl}$ fused to residues 58-97 of Gal 4 under the control of the lacU V5 promoter. pACTCLGF2 was made by replacing the HindIII-ECoRI fragment from $\mathrm{pAC} \lambda \mathrm{Cl}$ with the EcoRI-BstYI fragment from 
Table 1. Plasmids

\begin{tabular}{|c|c|c|}
\hline Plasmid & Relevant details & $\begin{array}{l}\text { Source/ } \\
\text { Reference }\end{array}$ \\
\hline $\mathrm{pAC} \lambda \mathrm{Cl}$ & $\begin{array}{l}\text { Cml }{ }^{\mathrm{R}} \text {; ori-pACYC184; } \\
\text { encodes } \lambda \mathrm{Cl}\end{array}$ & $\begin{array}{l}\text { Dove et al. } \\
\text { (1997) }\end{array}$ \\
\hline pACLGF2 & $\begin{array}{l}\text { Cml }{ }^{\mathrm{R}} \text {; ori-pACYC184; } \\
\text { encodes } \lambda \mathrm{Cl}(1- \\
236)+\mathrm{Gal} 4(58-97)\end{array}$ & this work \\
\hline $\mathrm{pACT} c \lambda \mathrm{cl}$ & $\begin{array}{l}\text { TC } c^{R} \text { ori-pACYC184; } \\
\text { encodes } \lambda c l\end{array}$ & this work \\
\hline pACTCLGF2 & $\begin{array}{l}\text { TC } C^{R} \text { ori-pACYC184; } \\
\text { encodes } \lambda \mathrm{Cl}^{(1-} \\
236)+\mathrm{Gal} 4(58-97)\end{array}$ & this work \\
\hline pBR322 & $A p^{R}$ cloning vector & $\begin{array}{l}\text { Bolivar et al. } \\
\text { (1977) }\end{array}$ \\
\hline $\mathrm{pBR} \alpha$ & $\begin{array}{l}A p^{R} ; \text { ori-pBR322; encodes } \\
\quad \alpha(1-329)\end{array}$ & $\begin{array}{l}\text { Dove et al. } \\
\text { (1997) }\end{array}$ \\
\hline $\operatorname{pBR} \alpha-G a l 11^{W T}$ & $\begin{array}{l}\text { Ap } p^{R} ; \text { ori-pBR322; encodes } \\
\alpha(1-248)+\text { Gal 11(263- } \\
\text { 352)WT }\end{array}$ & this work \\
\hline $\mathrm{pBR} \alpha-\mathrm{Gal} 11^{\mathrm{P}}$ & $\begin{array}{l}\text { Ap }^{\mathrm{R}} \text {; ori-pBR322; encodes } \\
\alpha(1-248)+\text { Gal 11(263- } \\
352) \mathrm{N} 342 \mathrm{~V}\end{array}$ & this work \\
\hline $\mathrm{pBRcl}-\omega$ & $\begin{array}{l}\text { Ap }^{R} ; \text { ori-pBR322; encodes } \\
\lambda \mathrm{cl}(1-236) \mathrm{WT}+2 \\
\text { Ala }+\omega(1-90)\end{array}$ & this work \\
\hline $\operatorname{pBRcl}(S 45 A)-\omega$ & $\begin{array}{l}\text { Ap }^{R} ; \text { ori-pBR322; encodes } \\
\lambda \mathrm{Cl}^{(1-236) S 45 A}+2 \\
\text { Ala }+\omega(1-90)\end{array}$ & this work \\
\hline $\mathrm{pBR} \Delta \mathrm{cl}$ & $\begin{array}{l}\text { ori-pBR322; does not } \\
\text { encode } \lambda \mathrm{cl}\end{array}$ & $\begin{array}{l}\text { Whipple et al. } \\
\text { (1994) }\end{array}$ \\
\hline $\mathrm{pBR} \omega-\mathrm{Gal} 11^{\mathrm{WT}}$ & $\begin{array}{l}\text { Ap }^{R} \text {; ori-pBR322; encodes } \\
\omega(1-90)+3 \\
\text { Ala +Gal 11(263-352)WT }\end{array}$ & this work \\
\hline $\mathrm{pBR} \omega-\mathrm{Gal} 11^{\mathrm{P}}$ & $\begin{array}{l}\text { Ap } p^{R} \text { ori-pBR322; encodes } \\
\omega(1-90)+3 \\
\text { Ala +Gal 11(263- } \\
\text { 352)N 342V }\end{array}$ & this work \\
\hline pE3C-1 & $\begin{array}{l}A p^{R} ; \text { ori-pBR322; encodes } \\
\quad \omega(1-90)\end{array}$ & $\begin{array}{l}\text { Gentry and } \\
\text { Burgess } \\
(1990)\end{array}$ \\
\hline pN S113 & $\begin{array}{l}\text { encodes LexA (1- } \\
202)+ \text { Gal 4(58-97) }\end{array}$ & $\begin{array}{l}\text { Farrell et al. } \\
\text { (1996) }\end{array}$ \\
\hline pLCF3 & encodes $\lambda \mathrm{cl}(1-132) \mathrm{S} 45 \mathrm{~A}$ & $\begin{array}{l}\text { J.K. Joung } \\
\text { (unplubl.) }\end{array}$ \\
\hline $\mathrm{pLX} 20$ & $\begin{array}{l}A p^{R} \text {; ori-pBR322; encodes } \\
\quad \lambda \mathrm{Cl}(1-236)\end{array}$ & $\begin{array}{l}\text { F. Whipple } \\
\text { (unpubl.) }\end{array}$ \\
\hline pSO23 & encodes Gal11(1-1081)WT & $\begin{array}{l}\text { Gaudreau et } \\
\text { al. (1997) }\end{array}$ \\
\hline pSO 32 & $\begin{array}{l}\text { encodes Gal 11(1-1081) } \\
\text { N 342V }\end{array}$ & $\begin{array}{l}\text { Gaudreau et } \\
\text { al. (1997) }\end{array}$ \\
\hline
\end{tabular}

$\left(\mathrm{Ap}^{\mathrm{R}}\right)$ Ampicillin resistant; $\left(\mathrm{Cml}^{\mathrm{R}}\right)$ chloramphenicol resistant; $\left(T C^{R}\right)$ tetracycline resistant.

pBR322 (encoding the $T c^{R}$ gene) and the appropriate BstYIHindlll fragment from PACLGF2.

Plasmid $p B R \alpha-G a l 11^{W T}$ is a derivative of $p B R \alpha$, confers $A p^{R}$, and encodes residues 1-248 of the $\alpha$ subunit of $E$. coli RN AP fused to residues 263-352 of wild-type Gal 11 under the control of tandem I pp and lacU V 5 promoters. $\mathrm{pBR} \alpha-\mathrm{Gal} 11^{\mathrm{WT}}$ was made by replacing the EcoRI-BamHI fragment from $\mathrm{pBR} \alpha$ with an EcoRI-BamHI-digested PCR product made using primers OL.R 1 and OL.18. The PCR product comprised a fragment of the 3 ' end of the $\mathrm{Cl}$ gene fused directly to the coding sequence of Gal11 (residues 263-352), and two PCR products (made using primers OL.R 1 and OL. 13 with $\mathrm{pBR} \alpha$ as template and primers OL. 15 and OL.18 with pSO23 as template, respectively) served as template for its generation. $\mathrm{pBR} \alpha-\mathrm{Gal} 11^{\mathrm{P}}$ was similarly made using pSO 32 instead of pSO23 as template.

Plasmid $p B R \omega-G a l 11^{\text {WT }}$ confers $A p^{R}$ and encodes residues 190 of the $\omega$ subunit of E. coli RN AP fused to three Ala residues, which in turn are fused to residues 263-352 of wild-type Gal 11. The expression of the $\omega-\mathrm{Gal} 11^{\mathrm{WT}}$ fusion protein is under the control of the lacUV 5 promoter. pBR $\omega-\mathrm{Gal} 11^{\mathrm{WT}}$ was made by replacing the $\mathrm{Ndel}-\mathrm{Sall}$ fragment from pLX20 with two fragments of DNA. One fragment (comprising a segment of the $\omega$ gene) was an Ndel-Notl-digested PCR product that was made using primers OL.41 and OL.42 with $\mathrm{pE} 3 \mathrm{C}-1$ as template. This introduces an Ndel site at the start and a Notl site at the $3^{\prime}$ end of $\omega$. The second fragment (comprising the $\mathrm{Gal} 11^{\mathrm{WT}}$ coding sequence from residues 263-352) was a Notl-Sall-digested PCR product that was made using primers OL.43 and OL.44 with pSO 23 as template. $\mathrm{pBR} \omega-\mathrm{Gal} 11^{\mathrm{P}}$ was similarly made using pSO 32 instead of pSO23 as template.

\section{$\beta$-Galactosidase assays}

SDS- $\mathrm{CHCl}_{3}$ permeabilized cells were assayed for $\beta$-galactosidase activity essentially as described (Miller 1972). Assays were performed at least three times in duplicate on separate occasions, with similar results. Values are the averages from one experiment and duplicate measurements differed by $<10 \%$.

\section{Primer extension analysis}

RNA isolation, primer labeling, primer extension assays, and transcriptional start site identification were as described previously (Dove et al. 1997).

\section{Acknowledgments}

We thank Mike Cashel, Luc Gaudreau, Dan Gentry, Keith Joung, Mark Ptashne, and Fred Whipple for plasmids and strains. We al so thank Yan YeXia for excellent technical assistance. We are very grateful to Keith Joung for helpful discussions and thank Mark Ptashne, Gareth King, John Mekalanos, and Bill Forrester for comments on the manuscript. This work was supported by $\mathrm{N}$ ational Institutes of Heal th grant GM 44025 (A.H.), by the $\mathrm{N}$ ational Science Foundation Presidential Young Investigator A ward (A.H.), and by an established investigatorship from the American Heart Association (A.H.).

The publication costs of this article were defrayed in part by payment of page charges. This article must therefore be hereby marked "advertisement" in accordance with 18 USC section 1734 solely to indicate this fact.

\section{References}

A pone, L.M., C.A. Virbasius, J.C. Reese, and M.R. Green. 1996 Yeast $\mathrm{TAF}_{11} 90$ is required for cell-cycle progression through $\mathrm{G}_{2} / \mathrm{M}$ but not for general transcription activation. Genes \& Dev. 10: 2368-2380.

Artsimovitch, I., K. Murakami, A. Ishihama, and M.M. Howe. 1996. Transcription activation by the bacteriophage M $\mathrm{u}$ M or protein requires the $\mathrm{C}$-terminal regions of both $\alpha$ and $\sigma^{70}$ subunits of Escherichia coli RN A polymerase. J. Biol. Chem. 271: 32343-32348. 
Barberis, A., J. Pearlberg, N. Simkovich, S. Farrell, P. Reinagel, C. Bamdad, G. Sigal, and M. Ptashne. 1995. Contact with a component of the polymerase II holoenzyme suffices for gene activation. Cell 81: 359-368.

Blatter, E.E., W. Ross, H. Tang, R.L. Gourse, and R.H. Ebright. 1994. Domain organization of RNA polymerase $\alpha$ subunit: C-terminal 85 amino acids constitute a domain capable of dimerization and DNA binding. Cell 78: 889-896.

Bolivar, F., R.L. Rodriguez, P.J. Greene, M.C. Betlach, H.L. Heynecker, and H.W. Boyer. 1977. Construction and chracterization of new cloning vehicles. II. A multipurpose cloning system. Gene 2: 95-113.

Burgess, R.R. 1969. Separation and characterization of the subunits of ribonucleic acid polymerase. J. Biol. Chem. 244: 6168-6176.

- - 1976. Purification and physical properties of E. coli RN A polymerase. In RNA polymerase (ed. R. Losick and M. Chamberlin), pp. 69-100. Cold Spring Harbor Laboratory, Cold Spring Harbor, NY.

Busby, S. and R.H. Ebright. 1994. Promoter structure, promoter recognition, and transcription activation in prokaryotes. Cell 79: 743-746.

Chatterjee, S. and K. Struhl. 1995. Connecting a promoterbound protein to TBP bypasses the need for a transcriptional activation domain. Nature 374: 820-822.

Dove, S.L., J.K. Joung, and A. Hochschild. 1997. Activation of prokaryotic transcription through arbitrary protein-protein contacts. N ature 386: 627-630.

Ebright, R.H. and S. Busby. 1995. The E. coli RN A polymerase $\alpha$ subunit: Structure and function. Curr. Opin. Genet. Dev. 5: 197-203.

Farrell, S., N. Simkovich, Y. Wu, A. Barberis, and M. Ptashne. 1996. Gene activation by recruitment of the RN A polymerase II holoenzyme. Genes \& Dev. 10: 2359-2367.

Gaal, T., W. Ross, E.E. Blatter, H. Tang, X. Jia, V.V. Krishnan, N. Assa-M unt, R.H. Ebright, and R.L. Gourse. 1996. DN A-binding determinants of the $\alpha$ subunit of RNA polymerase: Novel DNA-binding domain architecture. Genes \& Dev. 10: 16-26.

Gaudreau, L., A. Schmid, D. Blaschke, M. Ptashne, and W. Horz. 1997. RN A polymerase II holoenzyme recruitment is sufficient to remodel chromatin at the yeast PHO5 promoter. Cell 89: 55-62.

Gentry, D.R. and R.R. Burgess. 1986. The cloning and sequence of the gene encoding the omega $(\omega)$ subunit of Escherichia coli RNA polymerase. Gene 48: 33-40.

- - 1989. rpoZ, encoding the omega subunit of Escherichia coli RN A polymerase, is in the same operon as spoT. J. Bacteriol. 171: 1271-1277.

- - . 1990. Overproduction and purification of the omega subunit of Escherichia coli RNA polymerase. Protein Expr. Purif. 1: 81-86.

- - . 1993. Cross-linking of Escherichia coli RNA polymerase subunits: identification of $\beta^{\prime}$ as the binding site of $\omega$. Biochemistry 32: 11224-11227.

Gentry, D., H. Xiao, R. Burgess, and M. Cashel. 1991. The omega subunit of Escherichia coli K-12 RNA polymerase is not required for stringent RNA control in vivo. J. Bacteriol. 173: 3901-3903.

Gerber, J.S. and D.M. Hinton. 1996. An N-terminal mutation in the bacteriophage T4 motA gene yields a protein that binds DNA but is defective for activation of transcription. J. Bacteriol. 178: 6133-6139.

Gonzal ez-Couto, E., N. Klages, and M. Strubin. 1997. Synergistic and promoter-selective activation of transcription by re cruitment of transcription factors TFIID and TFIIB. Proc.
Natl. Acad. Sci. 94: 8036-8041.

Gralla, J.D. 1996. Activation and repression of E. coli promoters. Curr. Opin. Genet. Dev. 6: 526-530.

Hayward, R., K. Igarashi, and A. Ishihama. 1991. Functional specialization within the $\alpha$ subunit of Escherichia coli RNA polymerase. J. Mol. Biol. 221: 23-29.

Heil, A. and W. Zillig. 1970. Purification of bacterial DNAdependent RN A-polymerase from isolated subunits as a tool for the elucidation of the role of the subunits in transcription. FEBS Lett. 11: 165-168.

Hellman, J.D. and M.J. Chamberlin. 1988. Structure and function of bacterial sigma factors. Annu. Rev. Biochem. 57: 839-872.

Hengartner, C.J., C.M. Thompson, J. Zhang, D.M. Chao, S. Liao, A.J. Koleske, S. Okamura, and R.A. Young. 1995. Association of an activator with an RN A polymerase II holoenzyme. Genes \& Dev. 9: 897-910.

Hidal go, E. and B. Demple. 1997. Spacing of promoter elements regulates the basal expression of the soxS gene and converts SoxR from a transcriptional activator into a repressor. EMBO J. 16: 1056-1065.

Himmel farb, H.J., J. Pearl berg, D.H. Last, and M. Ptashne. 1990. GALIIP: A yeast mutation that potentiates the effect of weak GAL4-derived activators. Cell 63: 1299-1309.

Hochschild, A. 1994. How $\lambda$ repressor talks to RN A polymerase. Curr. Biol. 4: 440-442.

Hochschild, A. and M. Ptashne. 1986. Homologous interactions of lambda repressor and lambda Cro with the lambda operator. Cell 44: 925-933.

Hu, J.C. 1995. Repressor fusions as a tool to study protein-protein interactions. Structure 3: 431-433.

Igarashi, K., N . Fujita, and A. Ishihama. 1991. Identification of a subunit assembly domain in the al pha subunit of Escherichia coli RNA polymerase. J. Mol. Biol. 218: 1-6.

Inouye, C., P. Remondelli, M. Karin, and S. Elledge. 1994. Isolation of a cDN A encoding a metal response el ement binding protein using a novel expression cloning procedure: The one hybrid system. DNA Cell. Biol. 13: 731-742.

Ishihama, A. 1992. Role of the RNA polymerase $\alpha$ subunit in transcription activation. Mol. Microbiol. 6: 3283-3288.

Jeon, Y.H., T. Yamazaki, T. Otomo, A. Ishihama, and Y. Kyogoku. 1997. Flexiblelinker in the RN A polymerase al pha subunit facilitates the independent motion of the C-terminal activator contact domain. J. Mol. Biol. 267: 953-962.

Kim, Y.J., S. Bjorklund, Y. Li, M.H. Sayre, and R.D. Kornberg. 1994. A multiprotein mediator of transcriptional activation and its interaction with the C-terminal repeat domain of RN A polymerase II. Cell 77: 599-608.

Klages, N . and M. Strubin. 1995. Stimulation of RNA polymerase II transcription initiation by recruitment of TBP in vivo. Nature 374: 822-823.

Kustu, S., A.K. N orth, and D.S. Weiss. 1991. Prokaryotic transcriptional enhancers and enhancer-binding proteins. Trends Biochem. Sci. 16: 397-402.

Kuldell, N. and A. Hochschild. 1994. Amino acid substitution in the -35 recognition motif of $\sigma^{70}$ that result in defects in phage $\lambda$ repressor-stimulated transcription. J. Bacteriol. 176: 2991-2998.

Lee, J.H. and T.R. Hoover. 1995. Protein crosslinking studies suggest that Rhizobium meliloti $\mathrm{C}_{4}$-dicarboxylic acid transport protein $\mathrm{D}, \mathrm{a} \sigma^{54}$-dependent transcriptional activator, interacts with $\sigma^{54}$ and the $\beta$ subunit of RN A polymerase. Proc. Natl. Acad. Sci. 92: 9702-9706.

Lee, M. and K. Struhl. 1997. A severely defective TATA-binding protein-TFIIB interaction does not preclude transcriptional activation in vivo. Mol. Cell. Biol. 17: 1336-1345. 


\section{Dove and Hochschild}

Li, J.J. and I. Herskowitz. 1993. Isolation of ORC6, a component of the yeast origin recognition complex by a one-hybrid system. Science 262: 1870-1874.

Li, M., H. Moyle, and M.M. Susskind. 1994. Target of the transcriptional activation function of phage $\lambda \mathrm{cl}$ protein. Science 263: 75-77.

Miller, A., D. Wood, R.H. Ebright, and L.B. Rothman-Denes. 1997. RN A polymerase $\beta^{\prime}$ subunit: A target of DN A bindingindependent activation. Science 275: 1655-1657.

Miller, J.H. 1972. Experiments in molecular genetics. Cold Spring Harbor Laboratory, Cold Spring Harbor Laboratory, NY.

M orett, E. and M. Buck. 1989. In vivo studies on the interaction of RN A polymerase- $\sigma^{54}$ with the Klebsiella pneumoniae and Rhizobium meliloti nifH promoters. J. Mol. Biol. 210: 65-77.

Niu, W., Y. Kim, G. Tau, T. Heyduk, and R.H. Ebright. 1996. Transcription activation at Class II CAP-dependent promoters: Two interactions between CAP and RNA polymerase. Cell 87: 1123-1134.

Ptashne, M. and A. Gann. 1997. Transcriptional activation by recruitment. Nature 386: 569-577.

Rao, L., W. Ross, J.A. A ppleman, T. Gaal, S. Leirmo, P.J. Schlax, M.T. Record Jr., and R.L. Gourse. 1994. Factor independent activation of rrnB P1. An "extended" promoter with an upstream element that dramatically increases promoter strength. J. Mol. Biol. 235: 1421-1435.

Ross, W., K.K. Gosink, J. Salomon, K. Igarashi, C. Zou, A. Ishihama, K. Severinov, and R.L. Gourse. 1993. A third recognition element in bacterial promoters: DNA binding by the al pha subunit of RNA polymerase. Science 263: 1407-1413.

Russo, F.D. and T.J. Silhavy. 1992. Alpha: The Cinderella subunit of RNA polymerase. J. Biol. Chem. 267: 14515-14518.

Sambrook, J., E.F. Fritsch, and T. Maniatis. 1989. Molecular cloning: A laboratory manual, 2nd ed. Cold Spring Harbor Laboratory Press, Cold Spring Harbor, NY.

Sauer, R.T., S.R. Jordan, and C.O. Pabo. 1990. $\lambda$ repressor: A model system for understanding protein-DNA interactions and protein stability. Adv. Protein Chem. 40: 1-61.

Sternberg, N.L. and R. Maurer. 1991. Bacteriophage-mediated general ised transduction in Escherichia coli and Salmonella typhimurium. Methods Enzymol. 204: 18-43.

Summers, A.O. 1992. Untwist and shout: A heavy metal-responsive transcriptional regulator. J. Bacteriol. 174: 30973101.

Wang, M.M. and R.R. Reed. 1993. Molecular cloning of the olfactory neuronal transcription factor Olf-1 by genetic selection in yeast. Nature 364: 121-126.

Whipple, F.W., N.H. Kuldell, L.A. Cheatham, and A. Hochschild. 1994. Specificity determinants for the interaction of $\lambda$ repressor and P22 repressor dimers. Genes \& Dev. 8: 12121223.

Xiao, H., M. Kalman, K. Ikehara, S. Zemel, G. Glaser, and M. Cashel. 1991. Residual guanosine 3',5'-bispyrophosphate (ppGpp) synthetic activity of relA null mutants can be eliminated by spoT null mutations. J. Biol. Chem. 266: 59805990.

Xiao, H., J.D. Friesen, and J.T. Lis. 1995. Recruiting TATAbinding protein to a promoter: Transcriptional activation without an upstream activator. Mol. Cell. Biol. 15: 57575761. 


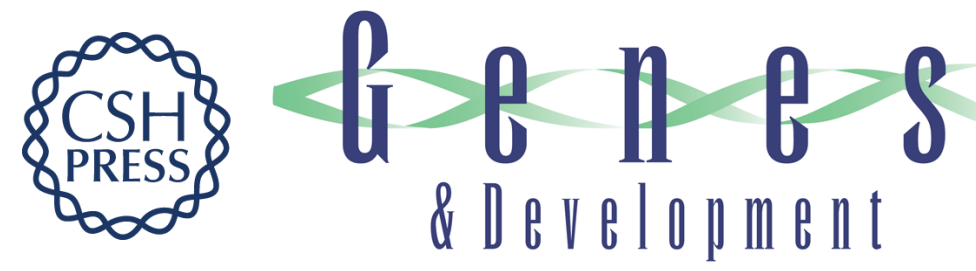

\section{Conversion of the $\omega$ subunit of Escherichia coli RNA polymerase into a transcriptional activator or an activation target}

Simon L. Dove and Ann Hochschild

Genes Dev. 1998, 12:

References This article cites 56 articles, 22 of which can be accessed free at:

http://genesdev.cshlp.org/content/12/5/745.full.html\#ref-list-1

License

Email Alerting Receive free email alerts when new articles cite this article - sign up in the box at the top Service right corner of the article or click here.

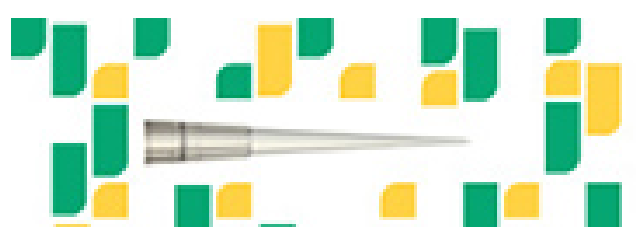

Focused on your science. 